A Republic OF Mind AND SPIRIT 



\section{A Republic OF}

\section{MIND ANDSPIRIT}

A Cultural History of American Metaphysical Religion

Catherine L. Albanese

Yale University Press

New Haven E London 
Published with assistance from the foundation established in memory of Philip Hamilton McMillan of the Class of 1894, Yale College.

Copyright $@ 2007$ by Yale University. All rights reserved. This book may not be reproduced, in whole or in part, including illustrations, in any form (beyond that copying permitted by Sections 107 and 108 of the U.S. Copyright Law and except by reviewers for the public press), without written permission from the publishers.

Set in Electra by Tseng Information Systems, Inc. Printed in the United States of America.

Library of Congress Cataloging-in-Publication Data Albanese, Catherine L.

A republic of mind and spirit : a cultural history of American metaphysical religion / Catherine L. Albanese.

p. $\mathrm{cm}$.

Includes bibliographical references and index. ISBN-13: 978-0-300-11089-0 (cloth : alk. paper) ISBN-10: 0-300-11089-8 (cloth : alk. paper)

1. United States-Religion. I. Title.

$$
\begin{gathered}
\text { BL2525.A435 } 2006 \\
299^{\prime} .93-\mathrm{dc} 22 \quad 2006013968
\end{gathered}
$$

A catalogue record for this book is available from the British Library.

The paper in this book meets the guidelines for permanence and durability of the Committee on Production Guidelines for Book Longevity of the Council on Library Resources.

$$
\begin{array}{llllllllll}
10 & 9 & 8 & 7 & 6 & 5 & 4 & 3 & 2 & 1
\end{array}
$$


For my loved ones in the spiritlandLouis and Theresa Albanese, Samantha, Selene, and Leah 
When I watch that flowing river, which, out of regions I see not, pours for a season its streams into me, I see that I am a pensioner; not a cause, but a surprised spectator of this ethereal water; that I desire and look up, and put myself in the attitude of reception, but from some alien energy the visions come.

-RAlPh WALdo emerson, "The Over-Soul"

Man is a god in ruins. When men are innocent, life shall be longer, and shall pass into the immortal as gently as we awake from dreams. . . .

... The kingdom of man over nature, which cometh not with observation, - a dominion such as now is beyond his dream of God,- he shall enter without more wonder than the blind man feels who is gradually restored to perfect sight.

- RALPh WALdo Emerson, Nature

The Western new United States of America convert intelligent observers to the belief that there is a REPUBLIC OF SPIRIT embosomed and gestating in the dominant political organism.

The only true America is the coming spiritual Republic.

-ANDREW JACKSON Davis, Beyond the Valley 